\title{
Discovery of a giant deep-sea valley in the Indian Ocean, off eastern Africa: The Tanzania channel
}

\author{
J. Bourget ${ }^{a,}{ }^{*}$, S. Zaragosi ${ }^{a}$, T. Garlan ${ }^{b}$, I. Gabelotaud ${ }^{b}$, P. Guyomard ${ }^{b}$, B. Dennielou ${ }^{d}$, N. \\ Ellouz-Zimmermann ${ }^{c}$, J.L Schneider ${ }^{a}$, and the FanIndien 2006 survey crew
}

\footnotetext{
a,Université de Bordeaux, UMR 5805, Avenue des Facultés, F-33405 Talence, France

${ }^{b}$ SHOM, Océanographie/Recherche, CS 92803, 29228 BREST Cedex 2, France

${ }^{\mathrm{c}}$ Institut Français du Pétrole (IFP), rue Bois Préau, France

d IFREMER, Géosciences Marines, Laboratoire Environnements Sédimentaires, BP70, 29280 Plouzané Cedex, France
}

\section{*: Corresponding author : J. Bourget, email address : j.bourget@epoc.u-bordeaux1.fr}

\begin{abstract}
:
During the Fanindien 2006 cruise of $R / V$ 'Beautemps-Beaupré', high resolution multibeam bathymetry, sub-bottom profiling and sediment coring was carried out along the East African margin, offshore Tanzania and Mozambique (Indian Ocean). The newly acquired data reveal the presence of a giant deep-sea valley (the Tanzania channel) that is more than $10 \mathrm{~km}$ wide at $4000 \mathrm{~m}$ water depth, along the continental rise. The valley remains $70 \mathrm{~m}$ deep and $7 \mathrm{~km}$ wide at $800 \mathrm{~km}$ from the Tanzania coast. Morphological comparison with worldwide submarine channels show that the Tanzania channel is one of the largest known submarine valleys. This discovery brings new light on development of submarine valleys that drain sediments originated from the East African Rift System (EARS) highlands (i.e. the Tanzania channel and its neighbor Zambezi channel located $\approx 1000 \mathrm{~km}$ southward). Both of the systems have a morphology markedly different to the classical sinuous, V-shaped channels located at similar latitudes (e.g. the Zaire or Amazon channels). Their submarine drainage system consists of a downslope converging tributary canyons joining a central trunk channel in the continental rise. The presence of such giant deep-sea drainage systems is probably linked to a strong structural control on the sediment pathway, associated to a massive sediment transfer towards the Indian Ocean in relation with the tectonic activity of the East African Rift System (i.e. the uplift periods trough midMiocene and Plio-Pleistocene times) and its interplay with the East African equatorial climate changes.
\end{abstract}

Keywords: submarine channel; turbidite system; East African Rift System; East African margin; Indian Ocean 


\section{Introduction}

The importance of submarine channels as preferred pathways for sediment transfer from the continents to deep-water environments has been recognized since the 1950's and the first discoveries of large deep-sea turbidite systems, e.g. the Amazon, Zaire, NAMOC systems and many more (Hesse et al., 1987; Flood et al., 1991; Piper and Normark, 2001; Babonneau et al., 2002). Although their morphology and internal architecture has been intensively studied since they are considered as important targets for oil exploration (Wynn et al., 2007), many recent works have also proved that the record of sediment flux to deep water turbidite systems can provide high resolution records of the land climate, sea-level changes and tectonics that affect the source area (Flood and Piper, 1997; Hesse and Khodabakhsh, 1998; Baztan et al., 2005; Maslin et al., 2005; Zühlsdorff et al., 2007; Piper et al., 2007; Toucanne et al., 2008). During the last few decades, many deep-sea research projects have focused on the west and northwest African margins, of major interest for both the petroleum industry and academia (Wynn et al., 2000; Babonneau et al., 2002; Saugy and Eyer, 2003; Antobreh and Krastel, 2006) The eastern African margin, however, remains very poorly studied. The recent FanIndien explorative cruise (R/V Beautemps Baupré, SHOM, 2006) crossed the western Indian Ocean from the Ormuz Strait (Gulf of Oman) to the Mozambique Strait. During this survey, a giant submarine valley (more than $10 \mathrm{~km}$ wide) was discovered offshore Tanzania (Fig. 1). Using EM120 multibeam bathymetry and imagery, high resolution 2D seismic and piston coring, the Tanzania channel could be described in detail along the $260 \mathrm{~km}$ of survey. Here we present the first results concerning its morphology between 4000 and $4500 \mathrm{~m}$ water depth.

\section{Regional Setting}

The eastern African margin formed during the break-up of Gondwana and relative drifting of the Africa and Madagascar continental blocks during Mesozoic and Cenozoic times (Salman and Abdula, 1995). The formation of the Indian Ocean at the end of the Mesozoic induced the creation of several marginal sedimentary basins, which finally formed the single system of the East African marginal sedimentary basin after the Late Cretaceous. The coastal plain of Tanzania and the Davie submarine ridge (Fig. 1) are also part of the south-eastern branch of the East African rift system (Chorowicz, 2005). At present day, the East African rift system is still propagating southward (Fig. 1), inducing consequent seismic activity (Fairhead and Stuart, 1982; Chorowicz, 2005).

The Tanzania continental shelf is very narrow (from 3 to $10 \mathrm{~km}$ ), except off the Rufiji delta where it extends on more than $40 \mathrm{~km}$. The upper continental slope develops from $-100 \mathrm{~m}$ to $2500 \mathrm{~m}$, with average slope values of 1,5 to $2^{\circ}$, that locally steepen to more than $4,5^{\circ}$. From 2500 to $-4000 \mathrm{~m}$ the lower slope develops with gentler gradients $\left(\sim 0,25^{\circ}\right)$. Then the slope passes to the continental rise (with an average slope of $\sim 0.08^{\circ}$ ) and finally reaches the Somalia abyssal plain down to $5000 \mathrm{~m}$ water depth.

The Tanzania channel is located basinward of a large drainage system, mainly composed by the Rufiji river $\left(180,000 \mathrm{~km}^{2}\right.$ drainage basin), the Ruvuma river $\left(163,500 \mathrm{~km}^{2}\right)$, and smaller rivers (Fig. 1). Both the Rufiji and Ruvuma rivers mouth are constituted by large deltas extending over more than $1,400 \mathrm{~km}^{2}$. The regional climate is controlled by the seasonal variability of the intertropical convergence zone (ITCZ), which brings rains during one single season corresponding to the austral summer (months of November-April) with prevailing NE monsoon associated with a southern position of the ITCZ (Gasse, 2000). The dry and windy season occurs in winter months (from May to October), when the region experiences a complete reversal in wind direction and stronger SE monsoon winds prevail. Cyclones are also a common regional feature, occurring generally during the months of January to March. 


\section{Results and Discussion}

Bathymetry and acoustic imagery were collected using the multibeam echosounder SIMRAD EM120 (12 KHz). Sub-bottom seismic lines were collected using the SBP 120 profiler, which offers deeper penetration and higher resolution $(\sim 1 \mathrm{~m})$ than conventional sub-bottom systems, with sweep frequencies between 2,5 and $7 \mathrm{kHz}$.

The data acquired between 4,000 and 4,500 $\mathrm{m}$ water depth show that the Tanzania channel is characterized by a rectilinear course (Fig. 2). A higher sinuosity is only observed where a rocky sea mount deflects the channel course (Fig. 2). At $4000 \mathrm{~m}$ water depth, the Tanzania channel is a relatively flat bottomed valley up to $12 \mathrm{~km}$ wide and $\sim 100 \mathrm{~m}$ deep, with steep walls (max. $\left.15^{\circ}\right)$, that develops along a very gentle slope $\left(0.09^{\circ}\right.$, Fig. 2$)$. Down-flank mass transport deposits (Fig. 3a) are observed, as well as small scour-like features (or internal channels), suggesting that erosion and by-pass dominate. The $100 \mathrm{~m}$ high levees are symmetrical, showing parallel, low amplitude to transparent acoustic facies (Fig. 3a), and large scale sediment waves that suggest overflow of the finest part of the channelled flows. However, it is also possible for sediment waves to be formed by bottom currents and sedimentological data would be needed to confirm the dominance of turbidity current processes on the channel flanks. Between 4100 to $4300 \mathrm{~m}$ water depth, the Tanzania channel floor is marked by an abrupt break of slope (reaching a maximum of $0.23^{\circ}$ ), associated with a deflection in the channel course (Fig. 2). Detailed bathymetry data show large and elongated incisions in the channel floor (scours): the largest one borders the right flank of the channel (Fig. 2). Downstream, this scour enlarges and forms a central thalweg, associated with the onset of an asymmetrical morphology and the development of internal terraces. In the third channel section, the slope values decrease to $0.03^{\circ}$ and the internal thalweg deepens and migrates laterally. The Tanzania channel course is then deflected by a $500 \mathrm{~m}$ high and $30 \mathrm{~km}$ long rocky mound (Fig. 2). Downstream, the internal channel becomes large enough to join both levees and to form a unique U-shaped, 5-7 km wide and $60-70 \mathrm{~m}$ deep valley (Fig. 2 and $3 \mathrm{~b}$ ). The flanks are steep, bordered by levees associated with low amplitude to transparent drape-like facies and sediment waves (Fig. 3b).

Our data do not cover the proximal and distal part of the Tanzania channel. However, the more recent bathymetric charts from ETOPO2 data show that the Tanzania channel is probably connected to a tributary canyon network (Fig. 1) that develop between a northern source off the actual Rufiji delta and a southern source off the Ruvuma river (Fig. 1). Distally, its basinward development is directly limited by the north-southward trending sea mounts delimiting the Somalia abyssal plain (Fig. 1), but the total system length could exceed 1000 km (Fig. 1).

Core FKS03 was recovered from the channel floor (Fig. 2). It is mainly composed of coarse grained sandy beds (mean grain sizes vary from $150 \mu \mathrm{m}$ to $365 \mu \mathrm{m}$, Fig. 4) that commonly show planar lamination and are vertically stacked through a sharp or slightly erosional contact (Fig. 4). The beds are found massive or slightly normally graded, suggesting a deposition by concentrated density currents and/or turbidity currents (Mulder and Alexander, 2001). The top of the core is constituted by thick, slightly bioturbated hemipelagic mud (Fig. 4).

Petrographical analysis and geochemical parameters measurements using millimeter-scale XRF analysis (Richter, 2006; Fig. 4) show that the sandy beds have a variable composition, i.e. foraminifer-rich turbidites (with high Ca content), detrital-rich sands (with abundant quartz and mica and high Ti/Ca ratio), and mixed deposits with abundant organic matter mainly composed of large wood fragments (Fig. 4). This variability may indicate several sources of reworked material for the gravity flows, although more data is required to detect the potential source areas.

Accelerator-mass-spectrometry (AMS) radiocarbon dating has been undertaken in hemipelagic beds immediately overlying the uppermost turbidite deposits (planktonic foraminifera Globorotalia menardii were separated from the $>150 \mu \mathrm{m}$ fraction). The sample provides an age of 12,455 +/- 45 years (uncalibrated), that yields an approximate age for the 
last turbidite activity in the Tanzania channel. This age corresponds to the period of postglacial sea level rise (Fairbanks, 1989; Siddall et al., 2003), commonly associated to sub-aerial delta development and sediment storage onto the shelf (Posamentier and Vail, 1989). Hence, this period corresponds to a decrease in sediment input and the end of turbidite activity in many turbidite systems, including the Indus and Zambezi fan in the Indian Ocean (Kolla et al., 1980; Prins and Postma, 2000).

The Tanzania channel morphology has been compared with the best known deep water turbidite systems (Fig. 5a). For similar water depths, it appears clearly that the Tanzania channel differs from point source submarine channels such as the Amazon or Zaire channels that are typically $\mathrm{V}$-shaped (mixed erosional and depositional), and have a meandering shape similar to subaerial rivers (Pirmez and Flood, 1995; Peakall et al., 2000; Babonneau et al., 2002; Wynn et al., 2007; Fig. 5a). In addition, the deep and wide morphology of the Tanzania channel show similarities with the Northwest Atlantic Mid-Ocean Channel (NAMOC), which is the longest (3800 km long) and widest deep sea channel in the world, located in the Labrador Sea (Hesse et al., 1987; Hesse and Rakofsky, 1992; Klaucke et al., 1998). These similarities become even clearer when using the classification method developed by Skene and Piper, 2006) based on the plot of the downchannel slope gradient versus the channel aspect ratio (Fig. 5b). Hence, grouping of the points for the Tanzania channel parameters is very close to those corresponding to the NAMOC, i.e. they are both mostly rectilinear and develop along very gentle slopes. Even more remarkable is the presence of the Zambezi submarine valley, located only $1000 \mathrm{~km}$ south from the Rufiji delta, which develops over $1800 \mathrm{~km}$ along the Indian Ocean (Kolla et al., 1980; Droz and Mougenot, 1987; Fig. 1). It is also characterized by a wide, mostly rectilinear "trunk-channel" morphology, similar to the NAMOC or Tanzania channels.

The occurrence of such giant deep sea valleys along equatorial passive margins is unusual, considering other deep sea systems located at same latitudes and hydroclimatic settings (e.g. the Amazon or Zaire fan; Fig. 5). The NAMOC development was largely controlled by successive melting of continental ice-sheets that fed glacial ice-streams delivering very large amounts of glacigenic material basinward (Hesse et al., 1997; Hesse et al., 1999) . Such basin drainage is characterized by huge volumes of sediment yield (Andrews and Syvitski, 1994). However, the sediment yield related to the present day Rufiji has been estimated to $95 \mathrm{t} / \mathrm{km}^{2} / \mathrm{yr}$ (Milliman and Syvitski, 1992). This value is equal or slightly larger than values calculated for the Zaire, Danube, Mississippi, or Nile rivers, and is also similar to those from the Zambezi River (Milliman and Syvitski, 1992). Hence, the present day values of sediment input into both the Zambezi and Tanzania systems cannot explain their unusually large development (i.e. "ice-sheet-fed" like morphology).

From the data available, the Tanzania channel is clearly "multi-sourced" (Fig. 1), i.e. several distributaries join the central valley in the continental rise. Similarly, the Zambezi valley is fed by a large network of distributaries (including canyons located off the Zambezi delta but also from the Madagascar continental slope). Furthermore, the Zambezi turbidite system is highly structurally controlled, as expected for the Tanzania channel system (i.e. both systems are flanked by morphological barriers such as the Davie Ridge and islands). The observation of sea-mounts bordering the flanks of the Tanzania channel (Fig. 1,2) is additional evidence of the probable structural control on the sediment pathway. Although of lesser extent, both the Tanzania and Zambezi systems have similarities with high-latitude turbidite systems such as the NAMOC, which submarine drainage system consists of downslope converging tributary canyons joining a central trunk channel, and that is also basement controlled and constrained by sea mounts (Hesse and Rakofsky, 1992). Hence, such giant valleys are composed of a multi-sourced, migrating upstream part and a stable, single downstream part (Droz and Mougenot, 1987; Hesse, 1989; Escutia et al., 2000). Inversely, the V-shaped, high sinuosity channels such as the Zaire, Cap Timiris, or Angola channels (Wynn et al., 2007) ) are "point-sourced" systems, with a stable upstream part and a divergent, migrating downstream part. 
The multi-source character of the feeder system and a strong structural control on the sediment pathway, probably associated to a large volume of sediment transferred, are likely to generate wide and stable, mostly 'rectilinear' valleys that develop along low gradient abyssal plains. Thus, occurrence of multi-sourced, giant turbidite valleys is not restricted to high-latitude, glacially-fed systems but may also occur at low-latitudes in tectonically active areas where a strong structural control highly confined the sediment pathways.

Both the Tanzania and Zambezi channels are sediment-fed by basin catchments that drain the East African Rift System highlands (Fig. 1). Droz and Mougenot (1987) showed that in the Zambezi case, the upstream migration and activation of the feeder system and the sediment infilling history were closely related to the East African Rift development. Hence it is likely that the Tanzania turbidite system development is similarly linked to the tectonic history of the EARS. Indeed, the development of the Zambezi valley in the middle Miocene (Droz and Mougenot, 1987) is synchronous with intense canyon incision off the Ruvuma delta (Walford et al., 2005), that has been attributed to a period of important increase in erosion and sediment supply to the Indian Ocean, in response to the uplift of the Tanzania craton and the East African Rift (Foster et al., 1997; Walford et al., 2005; Nicholas et al., 2007). The uplift phases of the East African Rift, that enhanced a huge transfer of sediment towards the East African marine basin, are likely to have contributed of the development of two giants, structurally -controlled turbidite valleys off East Africa.

\section{Conclusion}

Preliminary results show that the Tanzania channel is one of the largest submarine valleys in the world. Comparison with other deep water systems drainage suggests that its development is linked to an efficient source and feeder system, a strong structural control on its morphology and frequent and/or large volumes of sediment supply. The latter is possibly related to the strong earthquake activity upslope (Fig. 1), close to the possible canyon head location. Ongoing acquisition of geophysical and sedimentological data will document the system in its entire length, and provide further insight into how this system has developed in the particular climatic and tectonic East African margin context.

Both the Tanzania channel and its neighbour the Zambezi valley are multi-sourced, 'rectilinear' giant channels, which morphology is markedly different to the classic highsinuosity channels present at similar latitudes, e.g. the Zaire, Cap Timiris or Angola systems along the west African margin, or the Amazon channel in South America.

Furthermore, discovery of a second giant turbidite valley offshore East Africa supports the ideas of a direct link between the development of the East African Rift System, climate changes, and massive sediment load supply to the East African marine basin. Future investigations in the area will undoubtedly provide new perspectives on the timing and frequency of the last million year's basin filling and paleoenvironmental changes in East Africa. 


\section{Acknowledgments}

The authors are grateful to the SHOM and to all the scientists, technicians and crew members of the $R / V$ Beautemps-Beaupré for their technical assistance during the FanIndien "channel hunting" cruise. The authors are also grateful to J. St Paul, B. Martin and G. Chabaud for their technical assistance for core sampling. We gratefully acknowledge $\mathrm{T}$. Mulder and J.C. Faugères for their critical and constructive reading of an earlier version of this paper and William Fletcher for the English revision. Finally, we benefit from constructive reviews by Russell Wynn, John ?, and the co-editor David J.W. Piper.

Julien Bourget PhD thesis is funded by a DGA (French Ministry of Defence) - CNRS doctoral fellowship. This is an UMR CNRS 5805 EPOC (University Bordeaux 1) contribution n. 1697.

\section{References}

Andrews, J.T., Syvitski, J.P.M., 1994. Sediment fluxes along High-Latitude Glaciated Continental Margins (NE Canada and E Greenland). in Hay, W. (Ed.): Material Fluxes on the Surface of the Earth, National Academic Press, Washington, DC: 99-115.

Antobreh, A.A., Krastel, S., 2006. Morphology, seismic characteristics and development of Cap Timiris Canyon, offshore Mauritania: A newly discovered canyon preserved-off a major arid climatic region. Marine and Petroleum Geology, 23(1): 37-59.

Babonneau, N., Savoye, B., Cremer, M., Klein, B., 2002. Morphology and architecture of the present canyon and channel system of the Zaire deep-sea fan. Marine and Petroleum Geology, 19(4): 445-467.

Baztan, J., Berné, S., Olivet, J.L., Rabineau, M., Aslanian, D., Gaudin, M., Réhault, J.P., Canals, M., 2005. Axial incision: The key to understand submarine canyon evolution (in the western Gulf of Lion). Marine and Petroleum Geology, 22(6-7): 805-826.

Chorowicz, J., 2005. The East African rift system. Journal of African Earth Sciences, 43(1-3): 379-410.

Droz, L., Mougenot, D., 1987. Mozambique upper fan: origin of depositional units. A.A.P.G. Bulletin, 71: 1355-1365.

Escutia, C., Eittreim, S.L., Cooper, A.K., Nelson, C.H., 2000. Morphology and acoustic character of the antarctic Wilkes Land turbidite systems: Ice-sheet-sourced versus riversourced fans. Journal of Sedimentary Research, Section A: Sedimentary Petrology and Processes, 70(1): 84-93.

Fairbanks, G., 1989. A 17,000-year blacio-eustatic sea level record/ influence of glacial melting rates on the Younger Dryas event and deep-ocean circulation. Nature, 342: 637-642. Fairhead, J.D., Stuart, G.W., 1982. The seismicity of the East African rift system and comparison with other continental rifts. Continental and Oceanic Rifts, Geodynamic Series., 8: 41-61.

Flood, R.C., Manley, P.L., Kowsmann, K.O., Appi, C.J., Pirmez, C., 1991. Seismic facies and late Quaternary growth of Amazon submarine fan. In: P. Weimer and M.H. Link (Editors), Seismic Facies and Sedimentary Processes of Submarine Fans and Turbidite Systems. Springer-Verlag, NewYork, pp. 415-434.

Flood, R.D., Piper, D.J.W., 1997. Amazon fan sedimentation: the relationship to equatorial climate change, continental denudation, and sea-level fluctuations. In: R.D. Flood, D.J.W. Piper, A. Klaus and L.C. Peterson (Editors), Proceeding of the Ocean Drilling Program, Scientific Results, pp. 653-675.

Foster, A., Ebinger, C., Mbede, E., Rex, D., 1997. Tectonic development of the northern Tanzanian sector of the East African Rift System. Journal of the Geological Society, 154(4): 689-700.

Gasse, F., 2000. Hydrological changes in the African tropics since the Last Glacial Maximum. Quaternary Science Reviews, 19(1-5): 189-211. 
Hesse, R., Chough, S.K., Rakofsky, A., 1987. The Northwest Atlantic Mid-Ocean Channel of the Labrador Sea. V. Sedimentology of a giant deep-sea channel. Canadian Journal of Earth Sciences, 24(8): 1595-1624.

Hesse, R., 1989. "Drainage systems' associated with mid-ocean channels and submarine yazoos: alternative to submarine fan depositional systems. Geology, 17(12): 1148-1151.

Hesse, R., Rakofsky, A., 1992. Deep-sea channel/submarine-yazoo system of the Labrador Sea: a new deep-water facies model. American Association of Petroleum Geologists Bulletin, 76(5): 680-707.

Hesse, R., Klaucke, I., Ryan, W.B.F., Piper, D.J.W., 1997. Ice-sheet sourced juxtaposed turbidite systems in Labrador Sea. Geoscience Canada, 24(1): 3-12.

Hesse, R., Khodabakhsh, S., 1998. Depositional facies of late Pleistocene Heinrich events in the Labrador Sea. Geology, 26(2): 103-106.

Hesse, R., Klaucke, I., Khodabakhsh, S., Piper, D., 1999. Continental slope sedimentation adjacent to an ice margin. III. The upper Labrador Slope. Marine Geology, 155(3-4): 249+.

Klaucke, I., Hesse, R., Ryan, W.B.F., 1998. Seismic stratigraphy of the Northwest Atlantic Mid-Ocean Channel: growth pattern of a mid-ocean channel-levee complex. Marine and Petroleum Geology, 15(6): 575-585.

Kolla, V., Kostecki, J.A., Henderson, L., Hess, L., 1980. Morphology and Quaternary sedimentation of the Mozambique Fan and environs, southwestern Indian Ocean. Sedimentology, 27(4): 357-378.

Maslin, M., Vilela, C., Mikkelsen, N., Grootes, P., 2005. Causes of catastrophic sediment failures of the Amazon Fan. Quaternary Science Reviews, 24(20-21): 2180-2193.

Milliman, J.D., Syvitski, J.P.M., 1992. Geomorphic/tectonic control of sediment discharge to the ocean: the importance of small mountainous rivers. Journal of Geology, 100: 525-544.

Mulder, T., Alexander, J., 2001. The physical character of subaqueous sedimentary density flow and their deposits. Sedimentology, 48(2): 269-299.

Nicholas, C.J., Pearson, P.N., McMillan, I.K., Ditchfield, P.W., Singano, J.M., 2007. Structural evolution of southern coastal Tanzania since the Jurassic. Journal of African Earth Sciences, 48(4): 273-297.

Peakall, J., McCaffrey, B., Kneller, B., 2000. A Process Model for the Evolution, Morphology, and Architecture of Sinuous Submarine Channels. Journal of Sedimentary Research, 70(3): 434-448.

Piper, D.J.W., Normark, W.R., 2001. Sandy fans--from Amazon to Hueneme and beyond. AAPG Bulletin, 85(8): 1407-1438.

Piper, D.J.W., Shaw, J., Skene, K.I., 2007. Stratigraphic and sedimentological evidence for late Wisconsinan sub-glacial outburst floods to Laurentian Fan. Palaeogeography, Palaeoclimatology, Palaeoecology, 246(1): 101-119.

Pirmez, C., Flood, R.D., 1995. Morphology and structure of Amazon Channel. In: R.D. Flood, D.J.W. Piper, A. Klaus and e. al. (Editors), Proceedings of the Ocean Drilling Program, Initial Reports. Ocean Drilling Program, College Station, TX, pp. 23-45.

Posamentier, H.W., Vail, P.R., 1989. Eustatic controls on clastic deposition II - sequence and systems tract models. In: Wilgus and al. (Editors), Sea-level changes: an integrated approach. SEPM Special Publication, Tulsa, pp. 125-154.

Prins, M.A., Postma, G., 2000. Effects of climate, sea level, and tectonics unraveled for last deglaciation turbidite records of the Arabian Sea. Geology (2000): 375-378.

Richter, T.O., Van der Gaast, S.J., Koster, B., Vaars, A.J., Gieles, R., De Stigter, H.C., De Haas, H., Van Weering, T.C.E., 2006. The Avaatech XRF Core Scanner: technical description and applications to NE Atlantic sediments. In: R.G. Rothwell (Editor), New Techniques in Sediment Core Analysis. Special Publications. Geological Society, London, pp. 39-50.

Salman, G., Abdula, I., 1995. Development of the Mozambique and Ruvuma sedimentary basins, offshore Mozambique. Sedimentary Geology, 96(1-2): 7-41.

Saugy, L., Eyer, J.A., 2003. Fifty years of exploration in the Niger Delta (West Africa). AAPG Bulletin(78): 211-226. 
Siddall, M., Rohling, E.J., Almogi-Labin, A., Hemleben, C., Meischner, D., Schmelzer, I., Smeed, D.A., 2003. Sea-level fluctuations during the last glacial cycle. Nature, 423(6942): 853-858.

Skene, K.I., Piper, D.J.W., 2006. Late Cenozoic evolution of Laurentian Fan: Development of a glacially-fed submarine fan. Marine Geology, 227(1-2): 67-92.

Toucanne, S., Zaragosi, S., Bourillet, J.F., Naughton, F., Cremer, M., Eynaud, F., Dennielou, B., 2008. Activity of the turbidite levees of the Celtic-Armorican margin (Bay of Biscay) during the last 30,000 years: Imprints of the last European deglaciation and Heinrich events. Marine Geology, 247(1-2): 84-103.

Walford, H.L., White, N.J., Sydow, J.C., 2005. Solid sediment load history of the Zambezi Delta. Earth and Planetary Science Letters, 238(1-2): 49-63.

Wynn, R.B., Masson, D.G., Stow, D.A.V., Weaver, P.P.E., 2000. The Northwest African slope apron: a modern analogue for deep-water systems with complex seafloor topography. Marine and Petroleum Geology, 17(2): 253-265.

Wynn, R.B., Cronin, B.T., Peakall, J., 2007. Sinuous deep-water channels: Genesis, geometry and architecture. Marine and Petroleum Geology, 24(6-9): 341-387.

Zühlsdorff, C., Wien, K., Stuut, J.B.W., Henrich, R., 2007. Late Quaternary sedimentation within a submarine channel-levee system offshore Cap Timiris, Mauritania. Marine Geology, 240(1-4): 217-234.

\section{Figures}

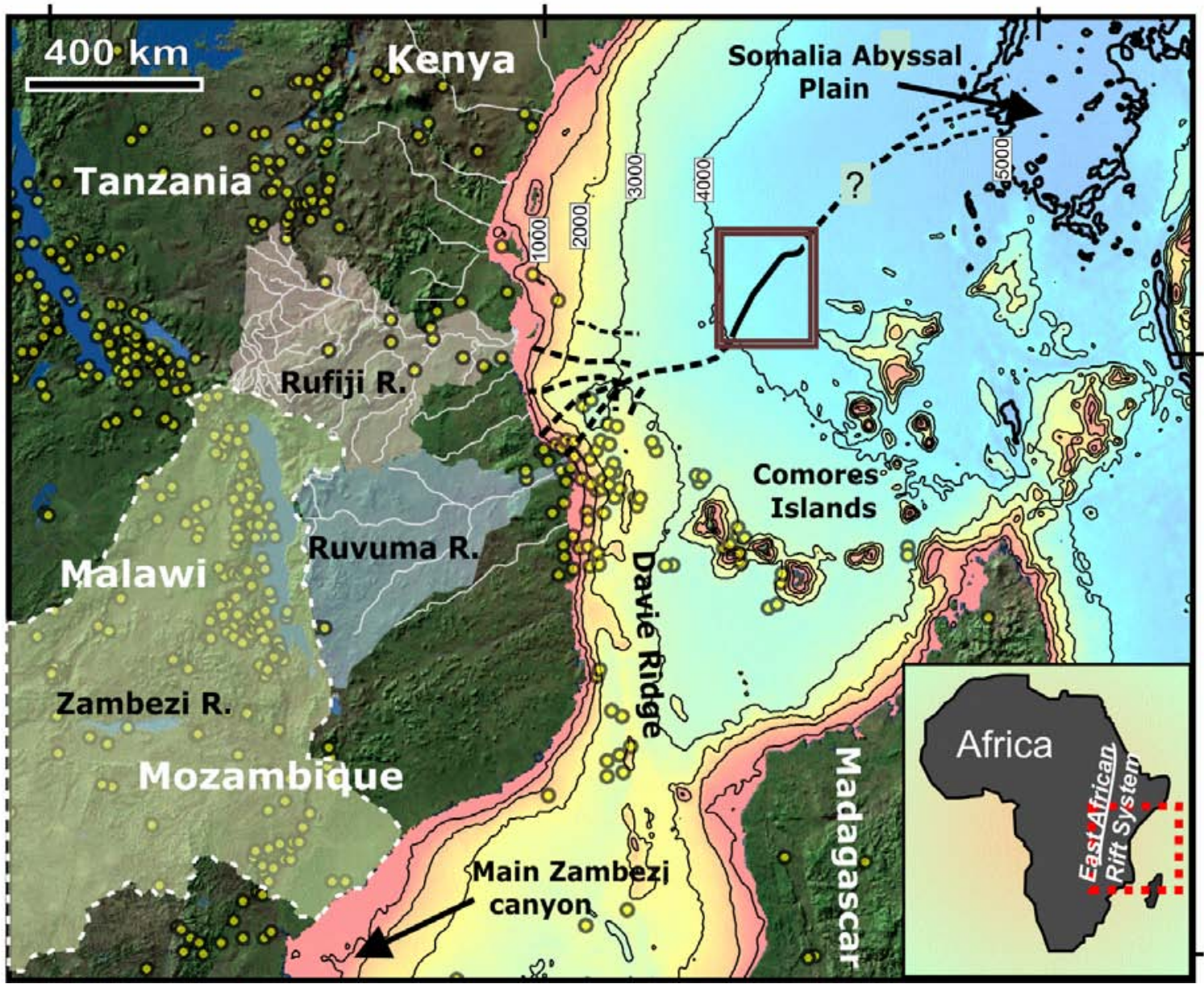


Fig. 1: Location map of the study area. Bathymetry data is from the ETOPO2 bathy charts. Bathymetric contours are in meters. The Somalia Abyssal plain is defined by the $-5,000 \mathrm{~m}$ contour. Onshore topography is derived from the NASA Shuttle Radar Topography Mission elevation model (http://www2.jpl.nasa.gov/srtm/index.html). Location of the main rivers (solid white lines) along the East African margin and localization of the Rufiji (shaded grey), Ruvuma (shaded blue), and Zambezi (shaded light green) rivers watersheds. Dashed line indicates the proximal and distal supposed trajectory of the Tanzania channel. Solid line indicates the position of the Tanzania channel along the $260 \mathrm{~km}$ of survey. Yellow circles indicate recent earthquake distribution in the area (Chorowizc, 2005).

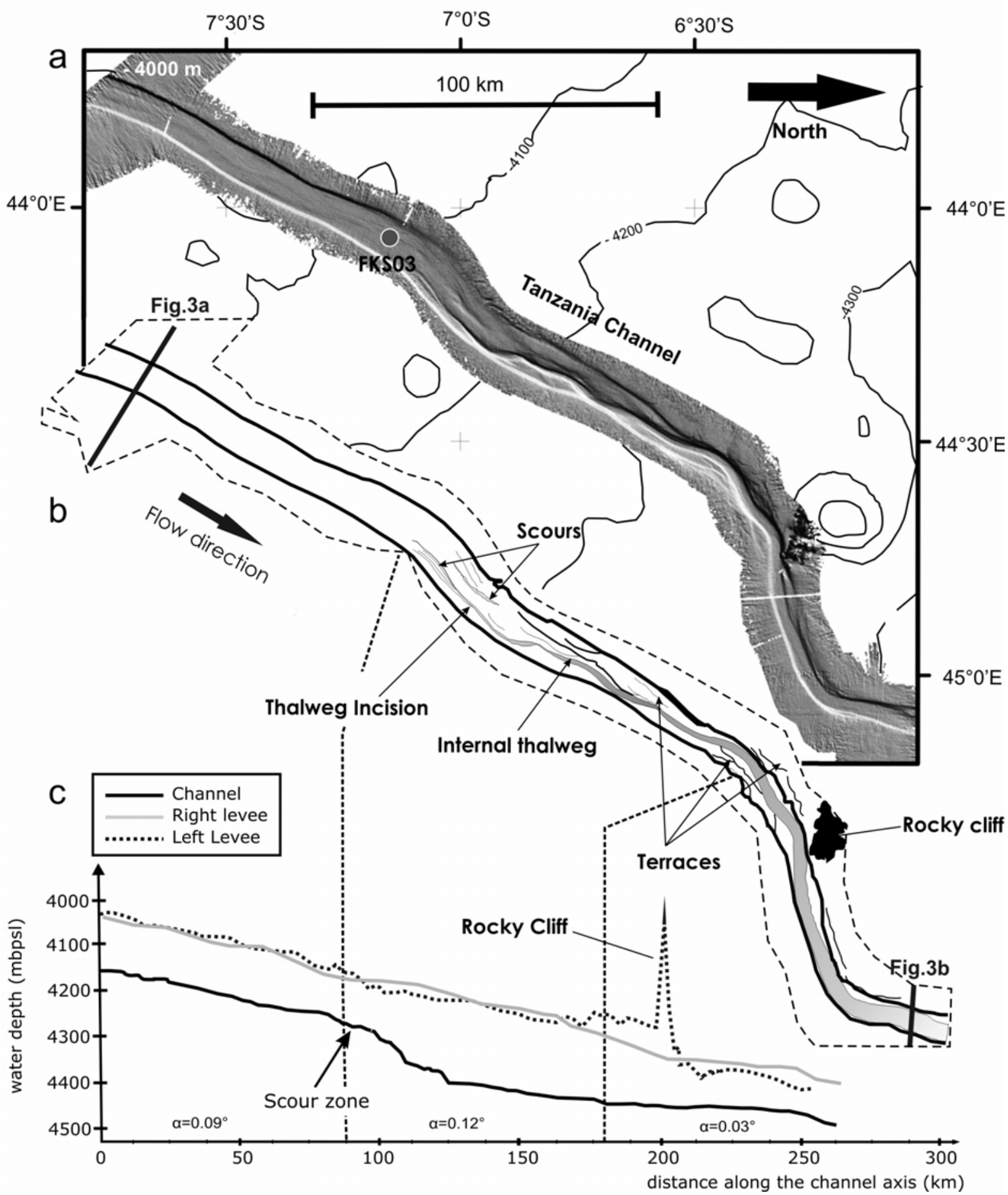


Fig. 2: a) Shaded bathymetry (EM12) of the Tanzania channel between 4,000 and 4,500 m water depth; bathymetry contour from the ETOPO2 database (in meters); b) Interpretative cartoon with the main morphological features, positions of the two SbP120 seismic lines (Fig. 3) and the FKS03 piston core (black circle); c) Slope profile plotted in the channel axis and along both right and left levees. Water depth is in meters below present sea level (mbpsl). Dashed vertical lines delimit the three morphological sections that have been determined based on average slope changes and general morphology. Average slope values for the three sections are indicated. Note the break of slope only observed in the channel axis. The presence of the rocky seamount is well observed along the left levee.

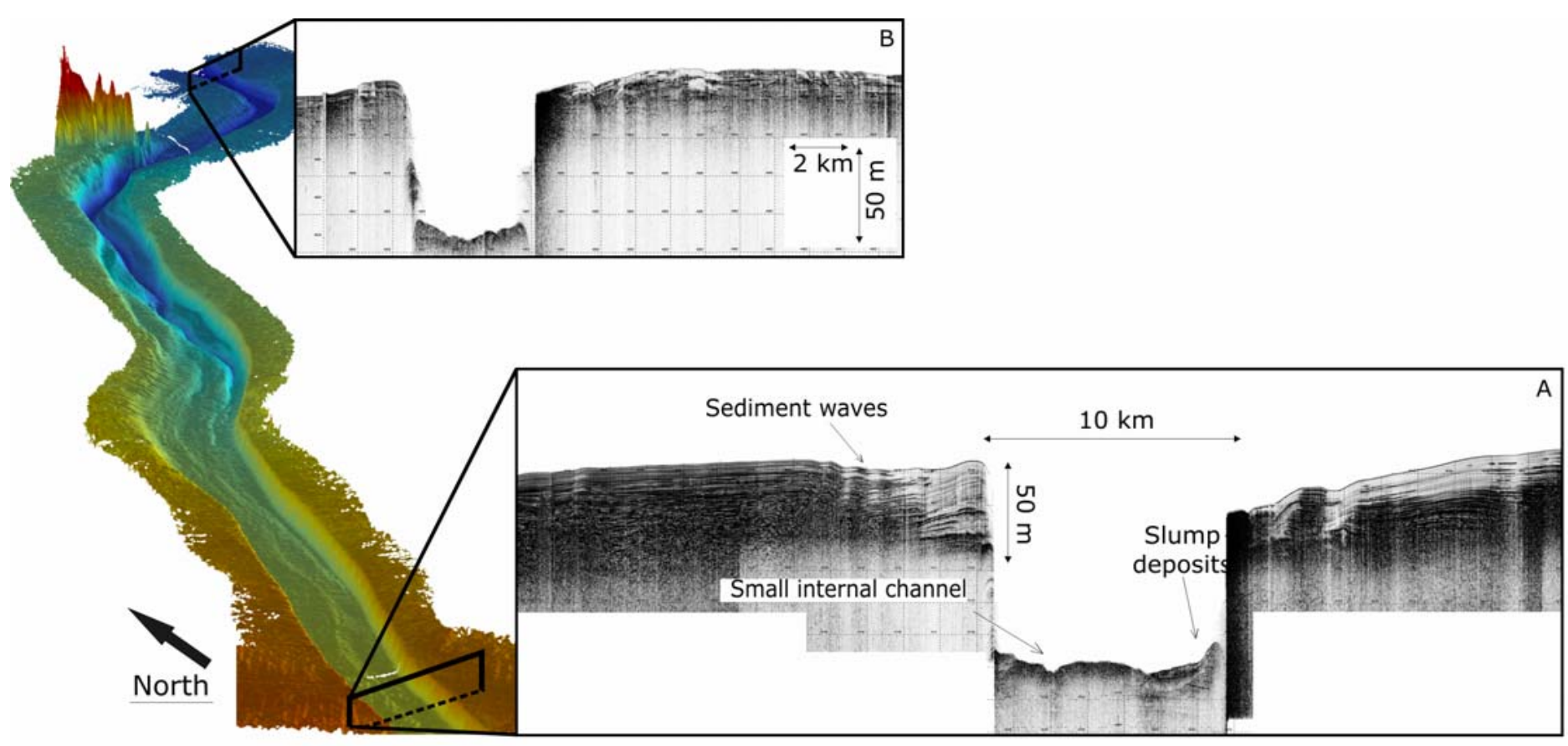

Fig. 3: 3D shaded bathymetry of the Tanzania channel along the $260 \mathrm{~km}$ of survey and SbP120 seismic at $-4,000 \mathrm{~m}$ depth (A) and $-4,500 \mathrm{~m}$ (B). Note the wide and deep flat-bottomed morphology of the channel upward and downward the incision zone (with initiation of a deep sinuous internal thalweg associated with terraces). Note also the rocky seamount that diverts the channel course. 


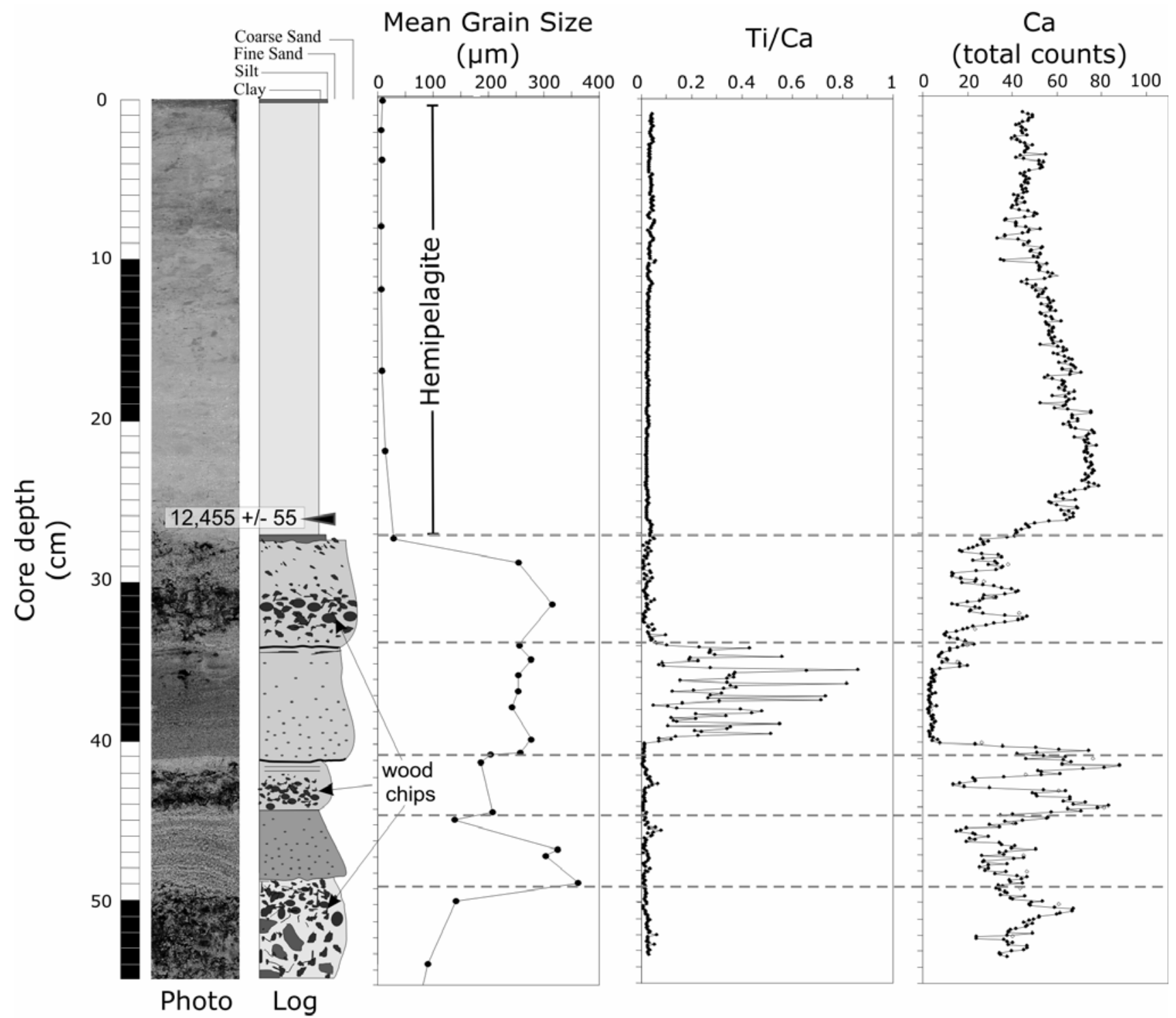

Fig. 4: Photography, graphic log, mean grain size $(\mu \mathrm{m}), \mathrm{Ti} / \mathrm{Ca}$ and $\mathrm{Ca}$ content (total counts) of the core FKS03, recovered in the channel floor (see location in Fig. 2). XRF data (semi quantitative measurements) have been obtained from the Avaatech XRF scanner (Richter et al., 2006). Black arrow indicates the position of the hemipelagic/pelagic clay sampled for AMS-radiocarbon dating (see text for more details) and the age obtained (uncalibrated age). 

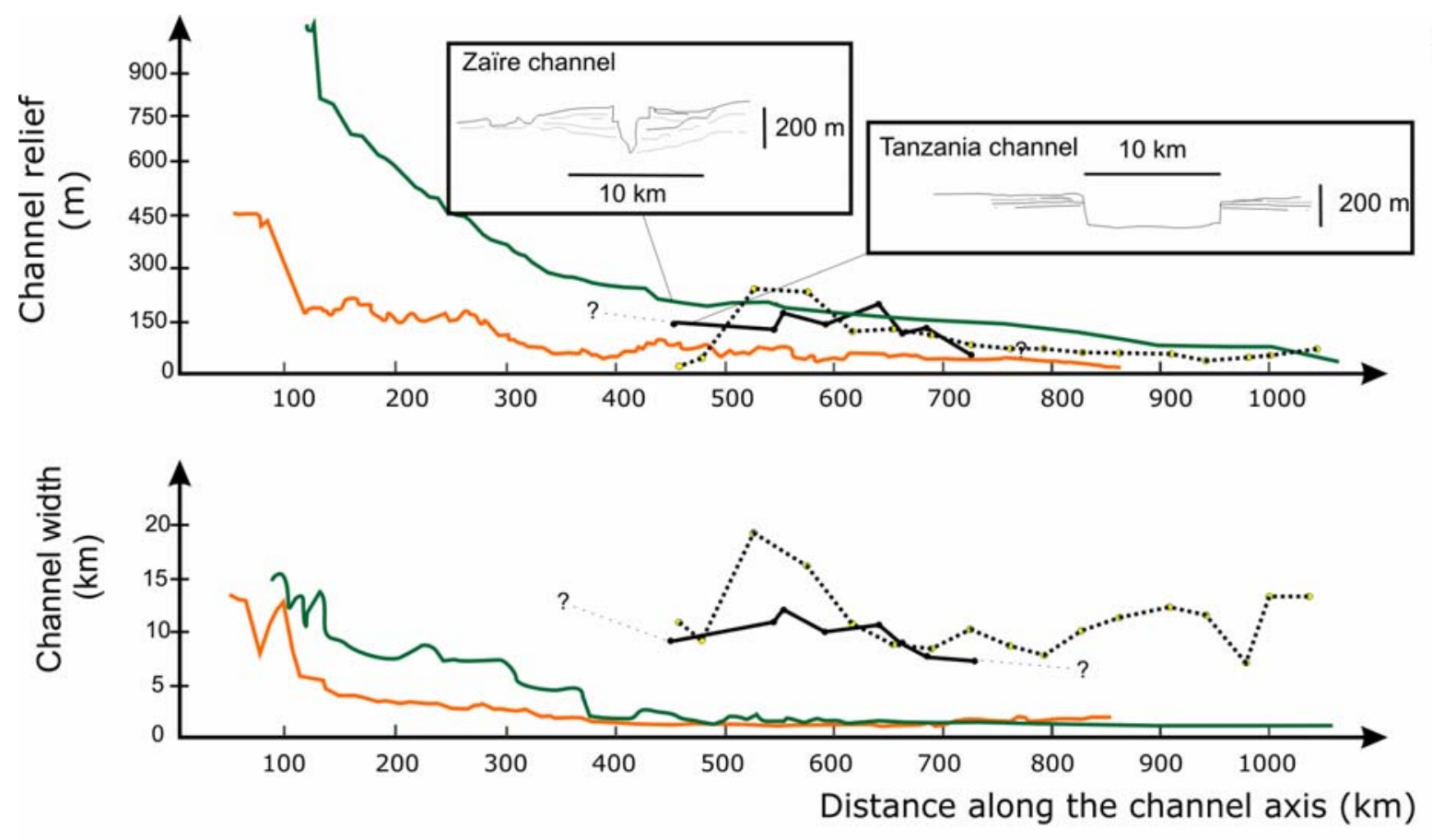

NAMOC

Zaire canyon and channel
... Tanzania channel Amazon canyon and channel

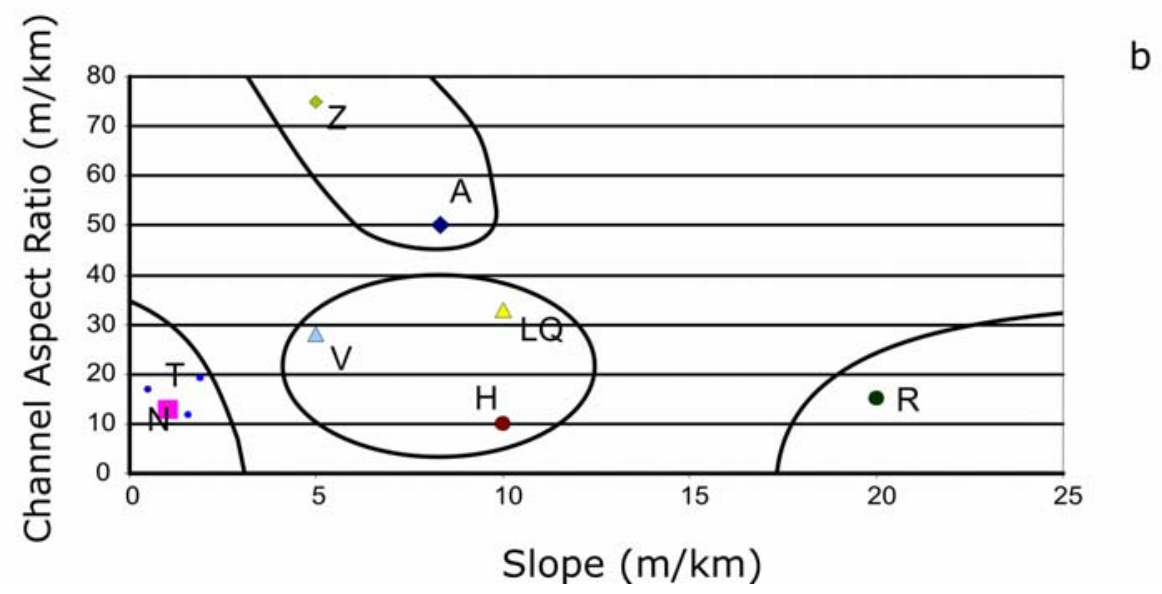

Fig. 5: Comparison of the Tanzania channel with some of the most studied deep-sea turbidite channels. a) Channel relief (average depth calculated from the bottom to the average height of the levees crest) and channel width (distance between the levees crest) plotted as function of the distance along the channel axis. Data from the Tanzania channel has been calculated at eight locations along the $260 \mathrm{~km}$ of survey. They are compared with the data from the Zaire channel (Babonneau et al., 2002), the Amazon channel (Pirmez and Flood, 1995), and the NAMOC channel (Hesse et al., 1987). b) Classification method developed by Skene and Piper (2006): plot of the channels aspect ratio (e.g. channel depth $(\mathrm{m}) /$ channel width $(\mathrm{km})$ ) versus the average slope gradient $(\mathrm{m} / \mathrm{km})$ calculated along the channel floor. Data from the Tanzania channel have been calculated from 5 profiles for each of the three morphology sections (see Fig. 2). Data from other systems e.g. the NAMOC (N), the Zaire channel (Z), Amazon channel (A), Var channel (V), the Laurentian Quaternary Channel (LQ), the Hueneme channel $(H)$, and the Reserve fan $(R)$ are obtained from Skene and Piper (2006). 